\title{
Relation between Cutting Surface Quality and Alloying Element Contents when Using a $\mathrm{CO}_{2}$ Laser
}

\author{
J. Litecká, J. Fabianová, S. Pavlenko
}

\begin{abstract}
This paper deals with the influence of material content on changes in the quality parameters of the cutting surface when cutting with a laser. The study focuses on experiments to find the effect of material structure and cutting parameters on surface roughness, Vickers microhardness and precision of laser cutting. The experimental results are shown in graphs which illustrate the suitability of materials for achieving required cutting surface quality parameters. These results can be used for optimizing production in practical applications using a laser cutting machine.
\end{abstract}

Keywords: laser cutting, alloyed steel, unalloyed steel, surface quality, cutting parameters.

\section{Introduction}

Laser material cutting is a progressive technology. However, due to high cost and high energy use, it is not as widely used in industry as traditional material cutting technologies. This progressive technology offers a wide area for researchers. It is necessary to focus on optimization and reengineering, using nonconventional ways of machining.

There are nowadays wide opportunities for using lasers in technological applications. Laser processing is a physical way of processing that is very clean and has high energy density. It is able to focus energy on a very small surface. It is very fast, and it can reduce material requirements.

\section{Cutting surface quality evaluation parameters after laser beam cutting}

The quality of the cutting area is determined by three basic cutting parameters: cutting speed; gap width and surface quality. The cutting speed should be as high as possible; the gap width should be as small as possible, and the surface quality is determined by $R_{a}$ based on STN, ČSN and $R_{z}$ based on DIN, EN ISO 9013. This standard is based on the English text of the European Standard EN ISO 9013:2002 "Thermal cutting - Classification of thermal cuts Geometrical product specification and quality tolerances".

The cutting area using a laser is characterized by analogy with most high-power cutting technologies. A grooved track is created by laser cutting as a result of the cyclic phase of the energy beam in interaction with the material by oscillation of hot-melt flow.
For certain types of material (mild steel, corrosion-resistant steel, ceramics, composite materials, titanium, plastics) the quality of surfaces cut by a $\mathrm{CO}_{2}$ laser with an additive gas, based on EN ISO 9013, can be characterized by the following values:

a) perpendicularity or angularity tolerance, $u$;

b) mean profile height, $R_{z}$.

The following characteristic values may be used in addition:

c) drag, $\Delta n$;

d) melting of the top edge, $r$;

e) possible occurrence of dross or melting drops on the lower edge of the cut.

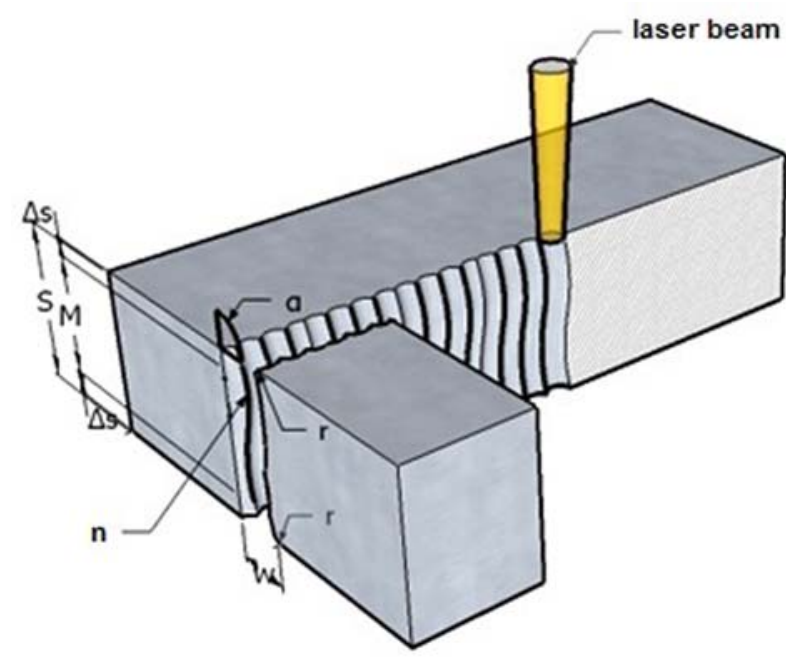

Fig. 1: Parameters for evaluating the cutting surface during laser cutting: $R_{z}$ - mean profile height, $n$-drag line, $\alpha$ - angle of beam deviation, $r$ - radius, $w$ - groove width, $S$ - material thickness, $\Delta s-$ thickness reduction, $M-$ measured area 


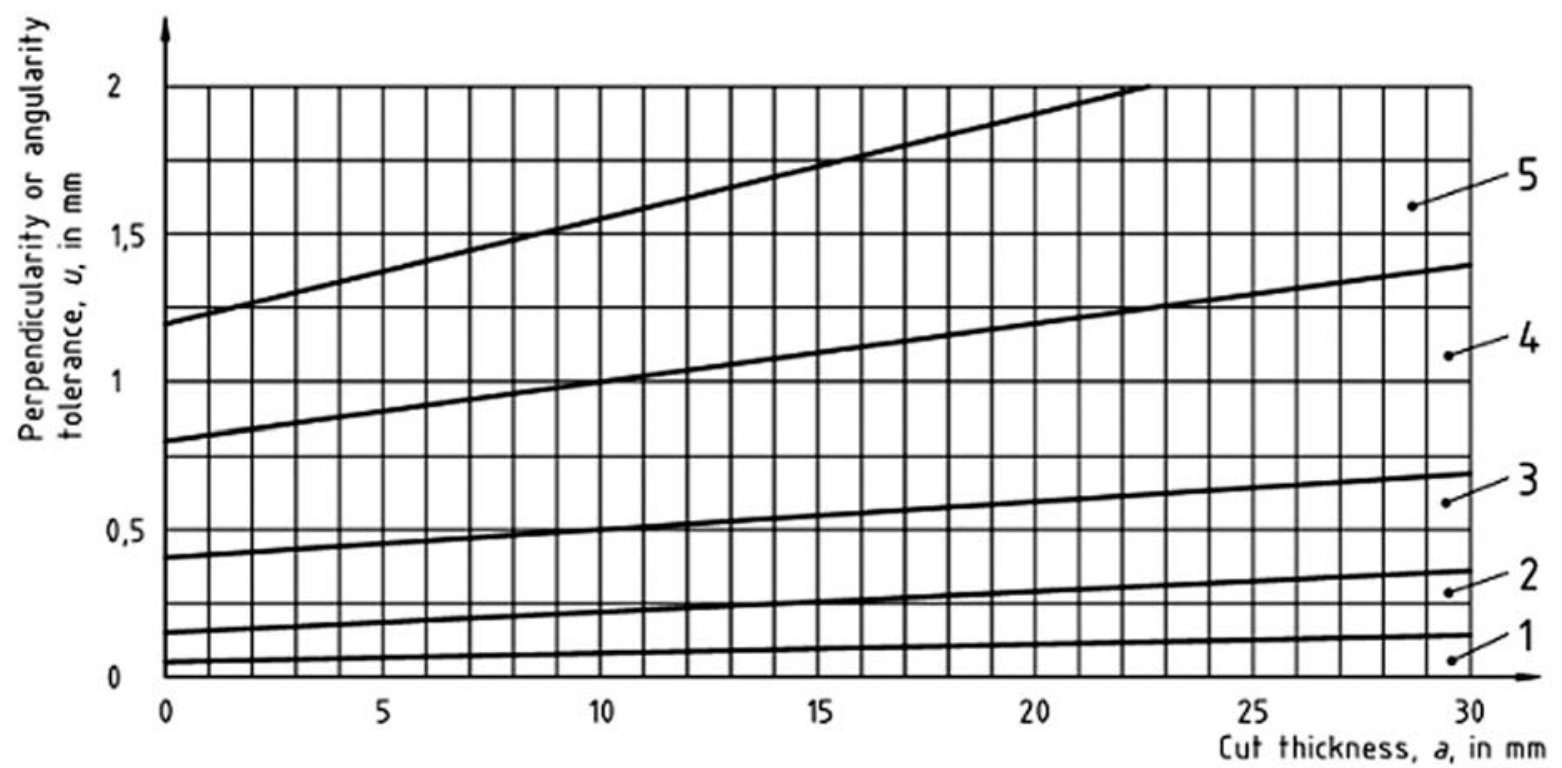

a) Perpendicularity or angularity tolerance, $u$-Work piece thickness up to $30 \mathrm{~mm}$

Fig. 2: Evaluation of the range of cutting surface quality based on perpendicularity or angularity by EN ISO 9013 [7]

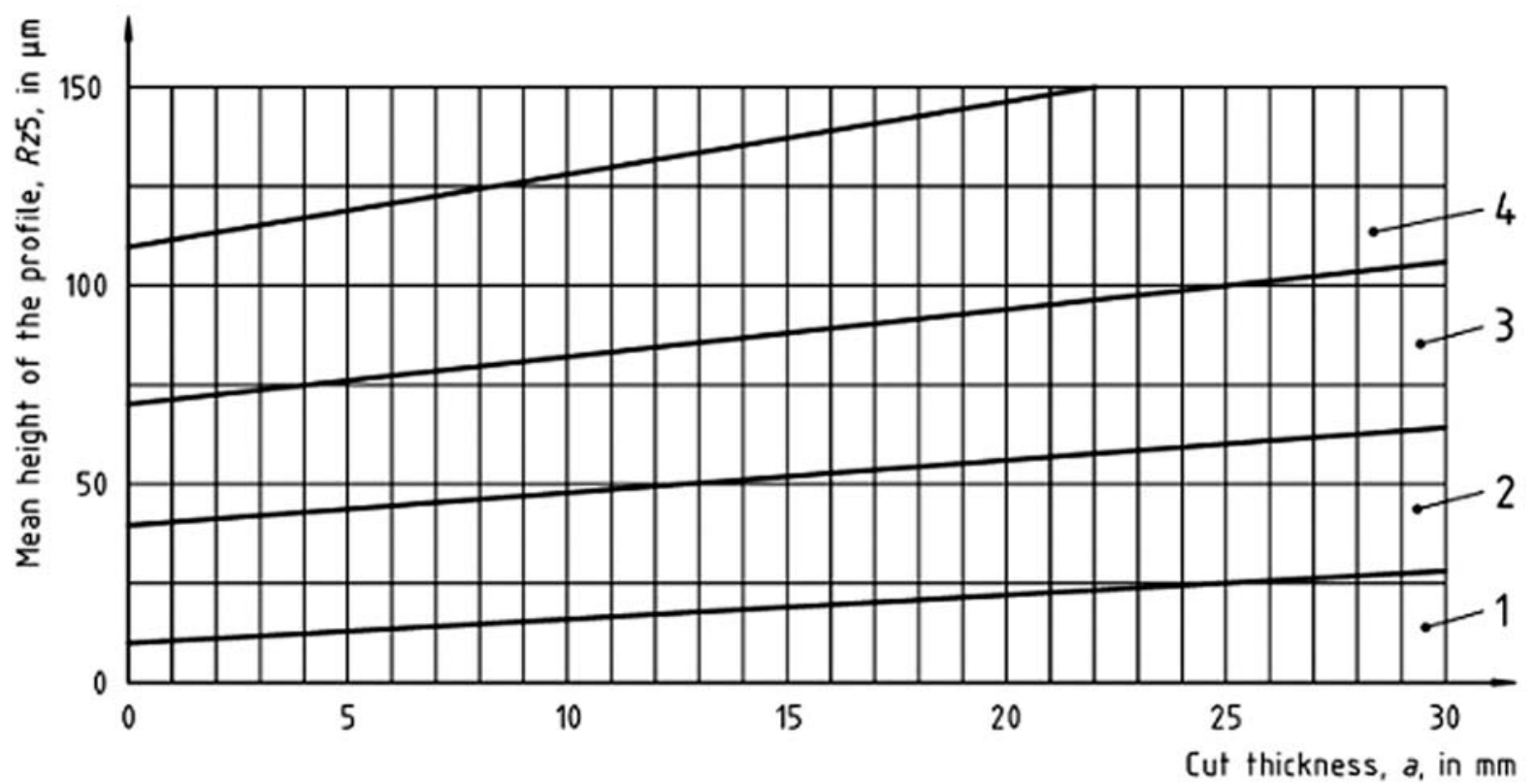

a) Mean height of the profile, Rz5 - Work piece thickness up to $30 \mathrm{~mm}$

Fig. 3: Evaluation of the range of cutting surface quality based on the mean height of profile $R_{z}$ by EN ISO 9013 [7]

In our experiments, we made precise measurements based on the EN ISO 9013 standard. The measurements focused on finding the perpendicularity, because the angle of the laser beam used in the experiments was $\alpha=0^{\circ}$. The perpendicularity value was determined according to the following equation:

$$
u=U P S-U N S
$$

where: $u$ - perpendicularity value, $U P S$ - measured value on the upper side of the cutting surface, $U N S-$ measured value on the lower side of the cutting surface.
The experimental surface roughness measurements focused on finding all roughness parameters $R_{a}, R_{q}$ and $R_{z}$. However, parameter $R_{z}$ was of greatest importance for determining the surface quality.

The measurement was supplemented by a Vickers microhardness measurement. This is not defined in EN ISO 9013 as a surface quality parameter. However, microhardness is a very important property of thermally cut materials because of its effects on the other processes, especially mechanical working. 


\section{Description of the experiment}

The following materials were chosen for an experiment to determine the quality characteristics of material cutting using a $\mathrm{CO}_{2}$ laser with different structures, i.e. with different alloys: S355J2C+N, QStE380TM and S2355JR. The samples were cut with dimensions $40 \times 40 \mathrm{~mm}, 6 \mathrm{~mm}$ in thickness. The samples were marked by laser engraving, and laser setting parameters were allocated for each sample. Each material was cut to six different parameters. Each sample was measured ten times, and the value was verified by the Grubbs test. The evaluation was made on the basis of the measured results. The measurements focused on the quality of the cutting surface.

\subsection{Quality parameter measurement procedure}

Surface roughness. The touch method was used for measuring the roughness parameters. A sharp point which moves on the surface of the measured object was used for finding the surface roughness value. The measurements were made using Mitutoyo Surftest SJ-301 mobile equipment. This is workshop equipment, but its parameters were convenient for the experiment. The test results can be displayed in several international standards DIN, JIS, ISO, ANSI.

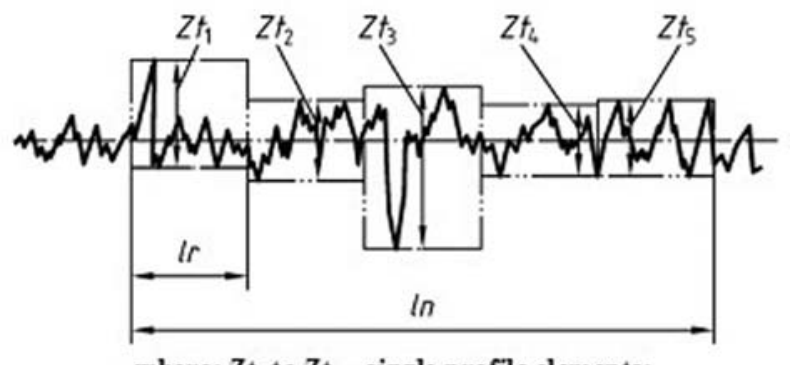

where: $\mathrm{Zt}_{1}$ to $\mathrm{Zt}_{5}$ - single profile elements;

ln - ex aluation length; $\mathrm{lr}$ - the single sampling length $/ 1 / 5$ of ln)

Fig. 4: Mean profile height $R_{z}$ by EN ISO 9013 [7]

Measuring of precision. Each sample was cut with nominal dimension $N D=40 \mathrm{~mm}$. The aim was to find the material and cutting parameters that are able to cut out the most precise dimension. The cutting surface was divided into two parts - upper side (Ups) and lower side (Uns), because the start and run surface of the material is unevenly melted. The measurement was made on ten points along a cut, $1 \mathrm{~mm}$ from the top cut edge and $1 \mathrm{~mm}$ from the bottom cut edge. The measurement principle is illustrated in Figure 5 . The measurement was performed using the 3D coordinate Rapid THOME ME 5008 measuring machine with high-precision measurement.

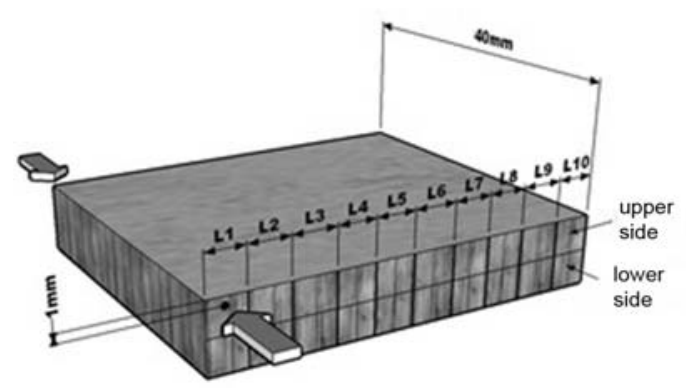

Fig. 5: Principle of precision measurement

Vickers microhardness. This test involves impressing an indentor (a diamond square pyramid with top angle $136^{\circ}$ ) into the test material. The samples were loaded by force $F=200 \mathrm{~g} f$ for a period $t=20 \mathrm{~s}$ in the normal direction on the surface of the sample. Ten impressions were made on each sample along the bottom cut edge at a distance of $0.20 \mathrm{~mm}$ from the edge, and the average microhardness was calculated nearest to the heat affected zone. Vickers microhardness is marked as $H V_{M}$, and is defined as force size $F$ on impression surface $S$. The principle of Vickers microhardness measurement is illustrated in Figure 6 .

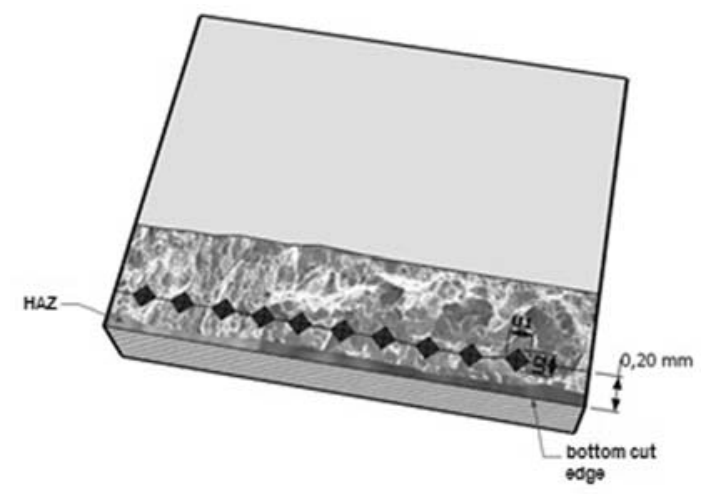

Fig. 6: Principle of Vickers microhardness measurement

\section{Experimental materials}

\section{$4.1 \quad \mathrm{~S} 355 \mathrm{~J} 2 \mathrm{C}+\mathrm{N}(1.0579+\mathrm{N})$ material normative EN 10025-2/04}

This is an alloyed construction steel with good ductility. It is used for steel structures, welded structures and machining parts with high tensile yield strength and for long and plane products that are hot rolled. It is for welded use, screwed and riveted structures with frequent cold shaping (blending, flanging, beading, profiling), static and dynamic stressed, for working at normal temperatures and at reduced temperatures to $-20^{\circ} \mathrm{C}$. It is suitable for all welded operations. It is suitable for cold shaping, with marking C. The final condition of the supplies is normalization rolled, with marking $+\mathrm{N}$. 
Table 1: Chemical properties of $\mathrm{S} 355 \mathrm{~J} 2 \mathrm{C}+\mathrm{N}$ material

\begin{tabular}{|l|c|c|c|c|c|c|c|}
\hline $\begin{array}{l}\text { Quality based on } \\
\text { EN 10 204-3.1 } \\
\text { U. S. Steel Kosice }\end{array}$ & \multicolumn{7}{|c|}{ Chemical analysis of melting with number 58 479 in \% } \\
\hline & $\mathrm{Nb}$ & $\mathrm{V}$ & $\mathrm{Ni}$ & $\mathrm{Mo}$ & $\mathrm{Cu}$ & $\mathrm{CEV}$ & $\mathrm{Cr}$ \\
\cline { 2 - 9 } & 0.04 & 0.003 & 0.01 & 0.002 & 0.03 & 0.414 & 0.03 \\
\cline { 2 - 9 } & $\mathrm{C}$ & $\mathrm{Mn}$ & $\mathrm{Si}$ & $\mathrm{P}$ & $\mathrm{S}$ & $\mathrm{Al}$ & \\
\cline { 2 - 9 } & 0.20 & 1.20 & 0.47 & 0.012 & 0.007 & 0.042 & \\
\hline
\end{tabular}

Table 2: Mechanical properties of material S355J2C+N

\begin{tabular}{|l|c|c|c|c|c|}
\hline \multirow{3}{*}{$\begin{array}{l}\text { Quality based on } \\
\text { EN 10 204-3.1 }\end{array}$} & \multicolumn{4}{|c|}{ Mechanical properties } \\
\cline { 2 - 6 } & Lower yield point & Breaking strength & Tensibility & \multicolumn{2}{|c|}{ KV } \\
\cline { 2 - 6 } & $R_{e}$ & $R_{m}$ & $A_{5}$ & & \\
& {$[\mathrm{MPa}]$} & {$[\mathrm{MPa}]$} & {$[\%]$} & {$\left[{ }^{\circ} \mathrm{C}\right]$} & {$[\mathrm{J}]$} \\
\hline S355J2C+N & 414 & 554 & 28.0 & -20 & 83 \\
\hline
\end{tabular}

\subsection{QStE 380 TM material normative SEW 092/90}

This is a micro-alloyed, small grained, high-quality steel with a low content of carbon, suitable for cold shaping. It is used for long and plane products which are hot rolled, e.g.: strips, sheet metals, wide steel. Final condition of supplies: thermomechanical rolled is marked TM. Steel quality marking of class QStE with a triple number which expresses the minimum lower yield point value $R_{e}$, which is measured in the normal direction in the direction of rolling.

\section{3 $\quad$ S235JR material normative EN 10025-2/04}

This is a non-alloyed high-quality construction steel. It is used for plane and long products hot rolled in thickness up to $250 \mathrm{~mm}$ with a certain peak load for $+20{ }^{\circ} \mathrm{C}$. This steel is not suitable for heat treatment, except in the case of products supplied with status $+\mathrm{N}$. These products can be hot shaped or normalized after delivery. Normalization after removing the internal stress is allowed. This steel is suitable for screwed and riveted constructions. Welding property: this steel is suitable for welding.

Table 3: Chemical properties of QStE380TM material

\begin{tabular}{l|l|c|c|c|c|c|c|c|c|}
\hline $\begin{array}{l}\text { Quality based on } \\
\text { EN 10 204-3.1 } \\
\text { U. S. Steel Kosice }\end{array}$ & \multicolumn{10}{|c|}{ Chemical analysis of melting with number 53019 in \% } \\
\hline \multirow{2}{*}{ QStE380TM } & $\mathrm{C}$ & $\mathrm{Mn}$ & $\mathrm{Si}$ & $\mathrm{P}$ & $\mathrm{S}$ & $\mathrm{Al}$ & $\mathrm{Nb}$ & $\mathrm{V}$ & $\mathrm{Ti}$ \\
\cline { 2 - 10 } & 0.08 & 0.90 & 0.01 & 0.009 & 0.006 & 0.039 & 0.04 & 0.001 & 0.013 \\
\hline
\end{tabular}

Table 4: Mechanical properties of QStE380TM material

\begin{tabular}{|l|c|c|c|c|c|}
\hline \multirow{2}{*}{$\begin{array}{l}\text { Quality based on } \\
\text { EN 10 204-3.1 } \\
\text { U. S. Steel Kosice }\end{array}$} & \multicolumn{4}{|c|}{ Mechanical properties } \\
\cline { 2 - 6 } & Lower yield point & Breaking strength & Tensibility & \multicolumn{2}{|c|}{ KV } \\
\cline { 2 - 6 } & $R_{e}$ & $R_{m}$ & $A_{5}$ & & \\
\hline QStE380TM & 482 & {$[\mathrm{MPa}]$} & {$[\%]$} & {$\left[{ }^{\circ} \mathrm{C}\right]$} & {$[\mathrm{J}]$} \\
\hline
\end{tabular}


Table 5: Chemical properties of S235JR material

\begin{tabular}{|l|c|c|c|c|c|c|c|c|c|}
\hline $\begin{array}{l}\text { Quality based on } \\
\text { EN 10 204-2.2 } \\
\text { U. S. Steel Kosice }\end{array}$ & \multicolumn{10}{|c|}{ Chemical analysis of melting with number 53019 in \% } \\
\hline \multirow{2}{*}{ S235JR } & $\mathrm{C}$ & $\mathrm{Mn}$ & $\mathrm{Si}$ & $\mathrm{P}$ & $\mathrm{S}$ & $\mathrm{Al}$ & $\mathrm{N}$ & $\mathrm{V}$ & $\mathrm{Ti}$ \\
\cline { 2 - 10 } & 0.19 & 1.50 & - & 0.045 & 0.045 & - & 0.014 & - & - \\
\hline
\end{tabular}

Table 6: Mechanical properties of S235JR material

\begin{tabular}{|l|c|c|c|c|c|}
\hline \multirow{2}{*}{$\begin{array}{l}\text { Quality based on } \\
\text { EN 10 204-3.1 } \\
\text { U. S. Steel Kosice }\end{array}$} & Mower yield point & Breaking strength & Tensibility & \multicolumn{2}{|c|}{ KV } \\
\cline { 2 - 6 } & $R_{e}$ & $R_{m}$ & $A_{5}$ & & \\
& {$[\mathrm{MPa}]$} & {$[\mathrm{MPa}]$} & {$[\%]$} & {$\left[{ }^{\circ} \mathrm{C}\right]$} & {$[\mathrm{J}]$} \\
\hline S235JR & 276 & 439 & 31.5 & 20 & 40 \\
\hline
\end{tabular}

Table 7: Group of all cutting parameters used in the experiment

\begin{tabular}{|c|c|c|c|c|c|c|c|}
\hline $\begin{array}{c}\text { Index of } \\
\text { cutting } \\
\text { parameters }\end{array}$ & $\begin{array}{c}\text { Cutting } \\
\text { speed }\end{array}$ & Power & $\begin{array}{c}\text { Gas } \\
\text { pressure }\end{array}$ & $\begin{array}{c}\text { Cutting } \\
\text { gap }\end{array}$ & $\begin{array}{c}\text { Focal distance } \\
\text { of lens }\end{array}$ & $\begin{array}{c}\text { Nozzle } \\
\text { diameter }\end{array}$ & Gas \\
\hline & {$[\mathbf{m} / \mathbf{m i n}]$} & {$[\mathbf{W}]$} & {$[\mathbf{b a r}]$} & {$[\mathbf{m m}]$} & {$[\mathbf{m m}]$} & {$[\mathbf{m m}]$} & \\
\hline $\mathbf{1}$ & 2.8 & 3200 & 0.8 & 0.3 & 7.5 & 1 & $\mathrm{O}_{2}$ \\
\hline $\mathbf{2}$ & 2.6 & 2700 & 0.6 & 0.3 & 7.5 & 1 & $\mathrm{O}_{2}$ \\
\hline $\mathbf{3}$ & 2.2 & 2000 & 0.6 & 0.3 & 7.5 & 1 & $\mathrm{O}_{2}$ \\
\hline $\mathbf{4}$ & 2 & 1800 & 0.6 & 0.3 & 7.5 & 1 & $\mathrm{O}_{2}$ \\
\hline $\mathbf{5}$ & 3.2 & 3200 & 0.8 & 0.3 & 7.5 & 1 & $\mathrm{O}_{2}$ \\
\hline $\mathbf{6}$ & 2.5 & 3200 & 0.8 & 0.3 & 7.5 & 1 & $\mathrm{O}_{2}$ \\
\hline
\end{tabular}

\section{Experimental results}

For the experiment, the samples were marked with letters of the alphabet and numerical indices to differentiate the materials and the cutting parameters. The materials were marked as follows:

- $\mathbf{S 3 5 5 J 2 C + N}$ by letter "B"

- QStE 380 TM by letter "C"

- S235JR by letter "D"

Each material was cut with six different cutting parameters (in Table 7 ). The cutting parameters were marked with numerical indices "1, 2, 3, 4, 5, 6", indicating changes in cutting speed, power and working gas pressure. The samples with the best quality results were selected for further tests. The surface roughness results are shown in Figure 7, Vickers microhardness (Figure 8) and precision of the cut surface to nominal distance (Figure 9).

Figure 7 illustrates three basic surface roughness parameters $R_{z}$ - average value of the five highest points and the five lowest points in the material; $R_{q}-$ sum of the average values of the highest and lowest points on the measured length; $R_{a}$ - average of all de- flections on the measured length. QStE 380 TM material showed the best surface roughness, with cutting parameters: cutting speed $-2.2 \mathrm{~m} \cdot \mathrm{min}^{-1}$, power $2000 \mathrm{~W}$, gas pressure -0.6 bar.

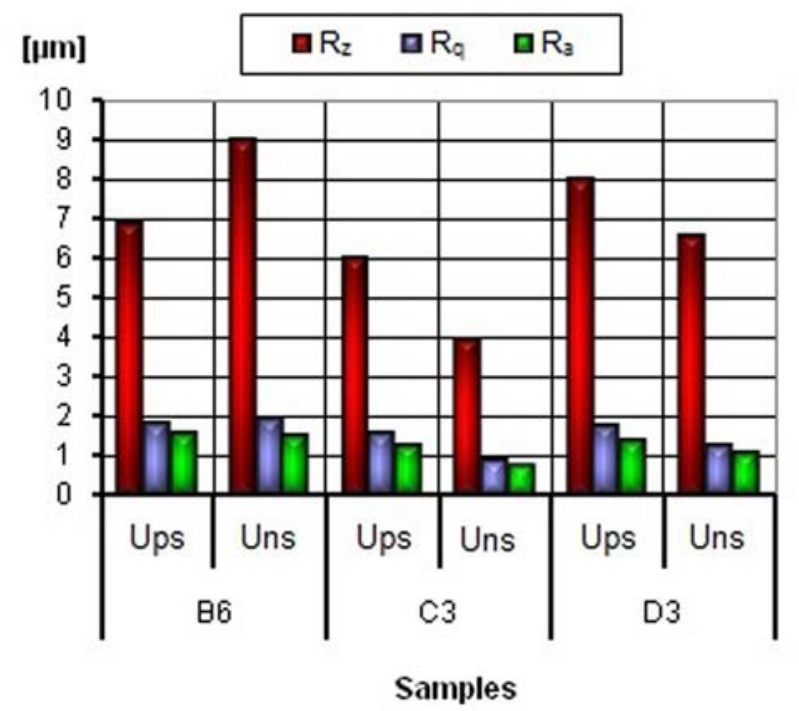

Fig. 7: Evaluation of surface roughness 
Figure 8 presents average Vickers microhardness values. These values were measured along the heataffected area to obtain the average microhardness value. Again, the best results were for QStE 380 TM material, but the cutting parameters were changed to: cutting speed $-2.5 \mathrm{~m} \cdot \mathrm{min}^{-1}$, power $-3200 \mathrm{~W}$, gas pressure -0.8 bar.

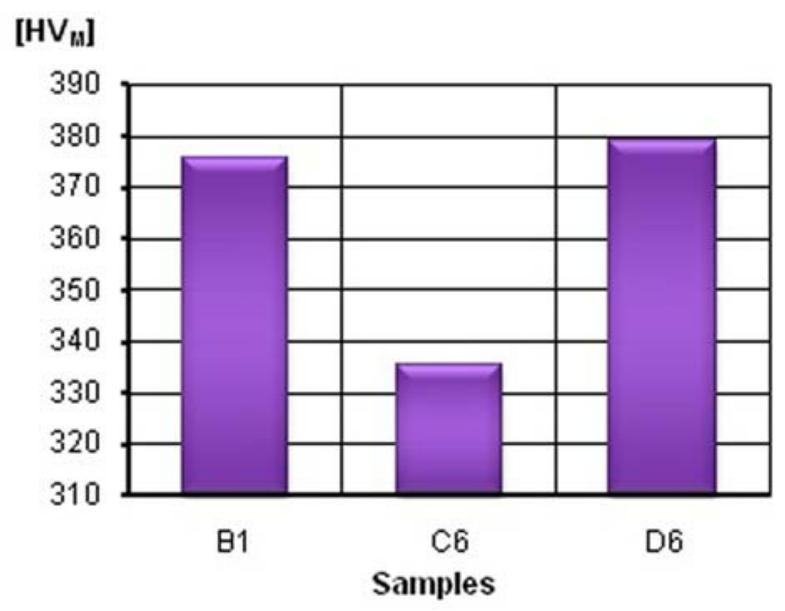

Fig. 8: Vickers microhardness evaluation

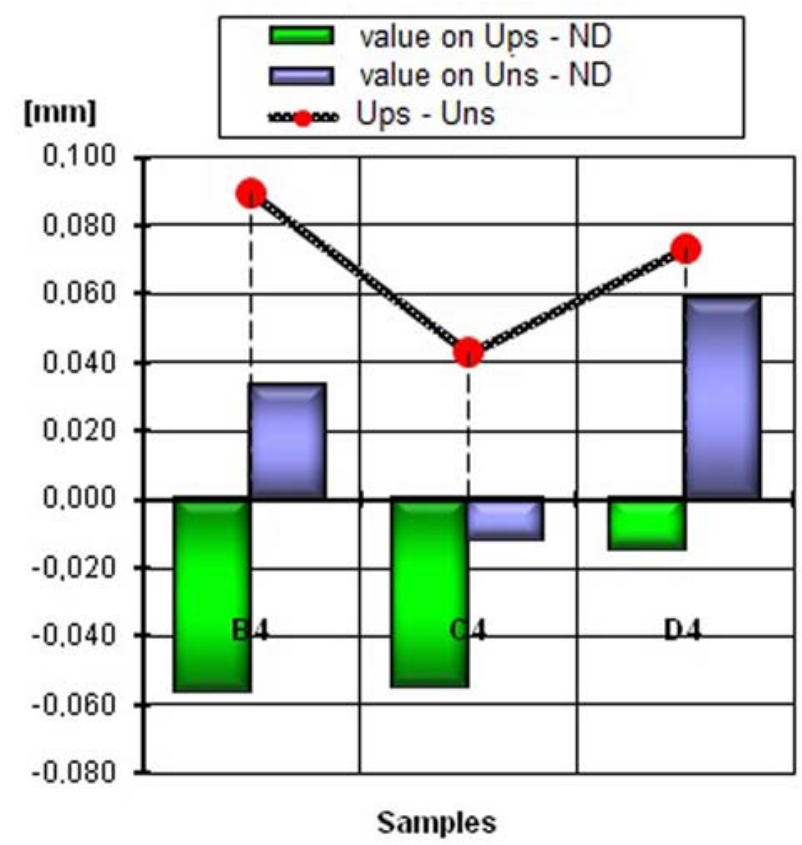

Fig. 9: Evaluation of dimensional inaccuracy

Figure 9 illustrates the relation of dimensional inaccuracy, i.e. the size of the deflection, on the nominal dimension. The start-up of the laser beam causes a change in material melting on the upper side (the melting on the upper side is greater than on the lower side). It is therefore very important to measure the divergence between the values on the upper side and on the lower side. The graph in Figure 9 shows that QStE 380 TM material again has the best precision values. For the purposes of the experiment, the upper side and the lower side of an experimental sample were melted. This was due to the increased exothermic reaction of the alloyed elements. A correction can be made by changing the cutting beam parameters. The cutting parameters for the highestprecision sample are: cutting speed $-2 \mathrm{~m} \cdot \mathrm{min}^{-1}$, power $-1800 \mathrm{~W}$, gas pressure $-0.6 \mathrm{bar}$.

\section{Conclusion}

Our experiment focused on finding the influence of materials with different content of alloy elements on the quality of the cut surface. The results of the test show that for cutting with a $\mathrm{CO}_{2}$ laser the best material is QStE $380 \mathrm{TM}$. This material has a low carbide and alloy element content. It had the best results for all measured quality parameters. The results also show that in order to achieve the required cut quality it is necessary to correct the cutting laser parameters, which also influence the cut quality. It is important in the component production process to determine the necessary priorities. These priorities depend on the subsequent processing or on the practical use of the products. It is very important to design an optimization solution for achieving the required results with minimum operating costs. Our results can help companies to improve the efficiency and cost-effectiveness of their production.

\section{References}

[1] Maňková, I.: Progresívne technológie. Vienala Košice, 2000, 275 p. ISBN 80-7099-430-4.

[2] Vasilko, K., Kmec, J.: Delenie materiálu. Datapress Prešov, 2003, 232 p. ISBN 80-7099-903-9.

[3] Havrila, M.: Progresívne technológie. TU v Košiciach, FVT so sídlom v Prešove. Prešov, 2002, 105 p. ISBN 80-7099-891-1.

[4] Rasa, J., Jindrova, R.: Nekonvenční technologie. In: MM Spektrum 2006, 7, p. 34. ISSN 1212-2572.

[5] Maščenik, J., Batešková, E., Halkko, J.: Change the structure of the material technology of thermal effects of drilling flowdrill. In: $S B W$ 2009: Robotization and automation in welding and other techniques: Slavonski Brod, 11.-13. 11. 2009. Mechanical Engineering Faculty, 2009, p. 187-190. ISBN 978-953-6048-51-9.

[6] Fečová, V., Barna, J., Litecká, J.: The using of $3 \mathrm{D}$ coordinate measuring machine into the control system of components made in engineering. In: Journal of Engineering and Technology for 
Young Scientists. Vol. 1, Issue 1 (2010), p. 11-16. ISSN 1338-2349.

[7] Standard EN ISO 9013:2002 Thermal cutting Classification of thermal cuts - Geometrical product specification and quality tolerances.

[8] Hatala, M.: Laser - nástroj budúcnosti. In: Strojárstvo, 2008, Issue 4, [online]:

http://www.strojarstvo.sk/docwww/SK/299/ 299.pdf

Ing. Juliána Litecká

Phone: +421051772 3796

E-mail: juliana.litecka@tuke.sk

Department of Technological Devices

Faculty of Manufacturing Technologies

with a seat in Prešov

Technical University in Košice

Štúrova 31, 08001 Prešov, Slovakia doc. Ing. Jarmila Fabianová, CSc.

Phone: +4210517723796

E-mail: jarmila.fabianova@tuke.sk

Department of Manufacturing Technologies Faculty of Manufacturing Technologies with a seat in Prešov

Technical University in Košice

Štúrova 31, 08001 Prešov, Slovakia

prof. Ing. Slavko Pavlenko, CSc.

Phone: +421051772 3796

E-mail: slavko.pavlenko@tuke.sk

Department of Technological Devices

Faculty of Manufacturing Technologies

with a seat in Prešov

Technical University in Košice

Štúrova 31, 08001 Prešov, Slovakia 